\title{
Sea Is History, Sea Is Witness: The Creation of a Prosopographical Database for the Sephardic Atlantic
}

\author{
Michael Studemund-Haléry*
}

Where are your monuments, your battles, martyrs?

Where is your tribal memory? Sirs,

in that grey vault. The sea. The sea

has locked them up. The sea is History.

DEREK WALCOTT, The Sea Is History, $1979^{1}$

During the Jewish modern period, ships bound for colonies in the Americas not only carried products and lamentably, also slaves, but equally members of the Portuguese nation, among them young and old, poor and rich, adventurers and refugees, forasteiros and itinerant talmidei hakhamim in need of assistance, merchants and speculators, widowers and widows, grooms and brides (and sometimes the ships returned the travelers back to the places from where they had originally embarked). The colonies in the Atlantic, which attracted many members of the recently established Jewish Portuguese communities in Hamburg, Amsterdam, and London, negotiated between different colonial empires at long social, ethnic and cultural boundaries, crossed religious borders and frontiers, and showed the blending of multiple Jewish traditions. ${ }^{2}$

* The generous financial assistance from the zeit Foundation Ebelin and Gerd Bucerius enabled me to carry out fieldwork in Suriname, Curaçao and Barbados. This project would not have been possible without the help of my colleagues Amalia S. Levi and Thomas Kollatz.

1 The sea as guardian and witness of history-few words could serve as a better introduction to the history of the Sephardic Atlantic, see Carmen Birkle and Nicole Waller, eds., "The Sea is History": Exploring the Atlantic (Heidelberg: Winter, 2006).

2 Wim Klooster, "Atlantic and Caribbean Perspective. Analyzing a Hybrid and Entangled World," in The Sea: Thalassography and Historiography in the Twenty-First Century, ed. Peter N. Miller (Ann Arbor: University of Michigan Press, 2013), 6o-83.

(C) MICHAEL STUDEMUND-HALÉVY, 2019 | DOI:10.1163/9789004392489_021

This is an open access chapter distributed under the terms of the prevailing CC-BY-NC License at the time of publication. 
Through the personal stories of these travelers, we learn of the challenges and opportunities that faced the émigré Jews in these new places, and the many ties that bound them to their erstwhile homes across the ocean. ${ }^{3}$ Records of their travels and experiences shed light on a multicultural "Jewish" or "Swimming" Atlantic. ${ }^{4}$

For those who voluntarily made the voyage on a "God-damn floating coffin," the other side of the Atlantic offered escape from hardship and the cares of daily life, with promises of marvel-filled adventure and exotic romance, but also more prosaic hopes for steady sources of employment and income or just the chance for a better life. For the unwilling voyagers, some of whom were banished by the Mahamad never to return and others who were to be allowed back to the motherland after a stipulated number of years, the Atlantic was a place of grief and loss. Only in rare cases was the journey undertaken with the intention to cultivate economic or family ties or establish new commercial ventures. ${ }^{5}$

Global Sephardic networks thus shaped the Atlantic into a Sephardic Atlantic and the Caribbean islands into Sephardic islands by building new cultures and bringing disparate cultures into contact for the first time, hence creating a vast marchland of Jewish civilization in the Americas and a unique Sephardic-Caribbean place, space, and culture. ${ }^{6}$ The Jewish Atlantic, however, was never exclusively Jewish. It included Christian colonists, colonial officials, sailors, soldiers, servants, enslaved men and women, but also indigenous inhabitants and Maroons in the hinterland. The Sephardic component comprised Jews and also New Christians, New Jews, Christian converts to Judaism, ${ }^{7}$ and Jewish converts to Christianity. This diverse group retained family, cultural,

3 Julia Philips Cohen and Sarah Abrevaya Stein, eds., Sephardi Lives. A Documentary History, 1700-1950 (Stanford: Stanford University Press, 2016).

4 Jonathan Schorsch, Swimming the Christian Atlantic. Judeoconversos, Afroiberians and Amerindians in the Seventeenth Century, 2 vols. (Leiden: Brill, 2009).

5 See, for example, for Amsterdam, Vibeke Sealtiel Olsen, Liste des Sépharades Portugais qui furent payés pour quitter Amsterdam, 1757-1813. Amsterdam 1999 [MS]; for Hamburg, see Michael Studemund-Halévy "Across the Waters. Sefardic Pioneers from Hamburg in the Caribbean," in A Sefardic Pepper-Pot in the Caribbean, ed. Studemund-Halévy (Barcelona: Tirocinio, 2016), 183-86.

6 Bernard Baylin, Concept and Contours (Cambridge, MA: Harvard University Press, 2005), 62.

7 See the spiritual odyssey of the seventeenth-century Christian Abraham Perengrino, alias Manuel Cardoso de Macedo $\left(15^{8} 5^{-16} 5^{2}\right)$, to Judaism, Benjamin N. Teensma, "De Levensgeschiedenis van Abraham Perengrino, alias Manuel Cardoso de Macedo," Studia Rosenthaliana 10 (1976): 1-36; Michael Studemund-Halévy, "Les aléas de la foi. Parcours d'un jeune Portugais entre église et synagogue," in Memoria. Festschrift für Michael Brocke, ed. Birgit Klein (Berlin: Metropol, 2005), 363-82; Ronnie Perelis, "Writing His Way into the Jewish People. Faith, Blood, and Community in Manuel Cardoso de Macedo's Vida del 
linguistic, and economic ties throughout most of its history, and eventually encompassed also the mulatto offspring of the Jewish slave owners in Barbados and Suriname. ${ }^{8}$ The strong ethnic endogamy motivated by religious, social, and cultural values coupled with the difficulty of finding spouses in the vicinity, often led to marriages among cross-or parallel cousins. Disapprobation of hypogamy (a female marrying someone of a lower social status or marrying "down") also induced the Sephardim to marry among themselves. ${ }^{9}$ Strong bonds of ethnic kinship hence translated into resilient relationships of commercial trust.

Consequently, the world of Caribbean Jews was, in a sense, a portable social, cultural, and economic sphere sustained by informal ethnic trading networks that functioned as a mode of advancement for its members. Jewish places and cultural spaces were filled with the itinerant Sephardic community that spread out across the Caribbean Sea. Many of these places were established under the shadow of Dutch Brazil-in Dutch-controlled Berbice, Curaçao, Demerara, Essequibo, Curaçao, Suriname (disputed between England and Holland), St. Eustatius, Tobago (disputed among various powers), Cayenne (in what is today French Guiana), English-controlled Barbados, Nevis, and Jamaica, and Danish-controlled St. Thomas. Among the first Sephardim to settle in the Caribbean basin were men and women who had initially fled the Iberian Peninsula and made their way first, either directly or indirectly, to Hamburg or Amsterdam and only later to Dutch Brazil. Among these itinerant families we can note the Abudiente, Cohen Belinfante, de Mercado, $\mathrm{Na}(\mathrm{h})$ mias, Pacheco,

buenaventurado Abraham Pelengrino," in idem, Narratives from the Sephardic Atlantic. Blood and Faith (Bloomington: Indiana University Press, 2016), 74-97.

8 The offspring of Sephardic men and non-Jewish African women were sometimes raised as Jews. The conversion entailed a formal ceremony carefully guided by rabbinical liturgical rites. The prayer book Sefer Berit Yitshak (Amsterdam, 1729), which has enjoyed many additional printings since its original publication, includes instructions for circumcising and ritually immersing male and female slaves for conversion. See also Jonathan Schorsch, Jews and Blacks in the Early Modern World (Cambridge: Cambridge University Press, 2004), 225-26; Brian Britt and Alexandra Cuffel, Religion, Gender, and Culture in the Pre-Modern World (New York: Palgrave Macmillan, 2015), 189.

9 Francesca Trivellato, The Familiarity of Strangers: The Sephardic Diaspora, Livorno, and Cross-Cultural Trade in the Early Modern Period (New Haven: Yale University Press, 2009); Alan F. Benjamin, Jews of the Dutch Caribbean. Exploring Ethnic Identity in Curaçao (London: Routledge, 2002). 
traceable in Recife, ${ }^{10}$ Barbados, Martinique, Antigua, St. Kitts, Nevis, ${ }^{11}$ Boston, New York, Newport, London, and Hamburg. ${ }^{12}$

Sephardic Jewishness thus bridged the Caribbean Sea and reached across the Atlantic to France, England, Amsterdam, Hamburg and the ancestral Iberian Peninsula, mirroring the post-expulsion dispersal of Sephardic conversos and "New Jews."13 The cultural coherence that was the result of multiple and intersecting networks of Jewish groups of Sephardic Jews (Spanish and Portuguese), New Christians (cristãos novos, conversos), crypto-Jews (Marranos), and later Ashkenazim, underpinned the remarkable flexibility of these groups and their capacity to cross religious, political, and cultural divides. This was a boon to the new wave of Jewish exiles to the Caribbean who found themselves in the front row of the European invasion of the New World and the establishment of the first European trade zones in the Americas. ${ }^{14}$

The webs of Sephardic communal affiliation were, however, slow to fall in line with Imperial divisions. Amsterdam long remained the supreme "mothercommunity" for the Sephardim of the Caribbean, as Evelyne Oliel-Grausz's work has shown in detail. ${ }^{15}$ Far from being exemplary "patriots," it could perhaps be argued that in the early modern period, the Sephardim in the Americas were closer to model "non-patriots," as Adam Sutcliffe points out, embedded as they were in particularly complex multiple networks of commerce and kinship, and thus remained necessarily aloof from the political rivalries among the various empires (and in part because of this, were better able to sustain trade

10 José A. de Gonsalves de Mello, Gente da Nação (Recife: Massangana, 1989).

11 Michelle M. Terrell, The Jewish Community of Early Colonial Nevis: A Historical Archaeological Study (Gainesville: University of Florida Press, 2005).

12 Some biographical sketches are part of my article "Across the Waters."

13 I borrow this excellent term from Yosef Kaplan, who uses it to describe the former conversos who embraced Judaism upon their arrival in open Jewish communities in Western Europe, such as Hamburg, Amsterdam, and London, see his article "Wayward New Christians and Stubborn New Jews," in Jewish History 8, nos. 1-2 (1994): 27-41; idem, Zwischen Neuchristen und neuen Juden. Die verschlungenen Wege von Kryptojuden und westlichen Sefarden in der Frühen Neuzeit (Trier: Kliomedia, 2014).

14 Thomas M. Truxes, "Trading Diasporas," in The Princeton Companion to Atlantic History, ed. Joseph C. Miller (Princeton, NJ: Princeton University Press, 2015), 456-62; Christian Cwik, "The Rise of Jewish Merchants Capitalists in the Caribbean: The Triangulation of Barbados, Jamaica and Curaçao," in A Sefardic Pepper-Pot in the Caribbean, ed. StudemundHalévy (Barcelona: Tirocinio, 2016), 13-29.

15 Evelyne Oliel-Grausz, "A Study in Intercommunal Relations in the Sephardi Diaspora: London and Amsterdam in the Eighteenth Century," in Dutch Jews as Perceived by Themselves and Others, ed. Yosef Kaplan and Chaya Brasz (Leiden: Brill, 2001), 41-58; OlielGrausz, "Networks and Communication in the Sephardi Diaspora: An Added Dimension to the Concept of Port Jews and Port Jewries," Jewish Culture and History 7 (2004): 61-76. 
with all parties during periods of conflict). ${ }^{16}$ On the other hand, as Sutcliffe highlights, the exposure of Sephardim "to a wide range of different cultures and religions, and their need to adapt in order to survive in contrasting and changing political regimes, promoted the development of particularly malleable political allegiances, and also of forms of religious heterodoxy,"17 that shaped the evolution of attitudes and values among the Western Sephardim over the course of this period.

The Caribbean basin became then a "New Heaven" for members of the transnational ethnic "nação portuguesa," where they found not only commercial and economic privileges but also religious, political, and civil freedoms and rights. In the Caribbean, the powerless diasporic Jew could be a global trader, merchant, shipper, slave and plantation owner, an equal of his Christian peer. The dispersal throughout the Atlantic world of Sephardim who were not bound by either territorial sovereignties or specific locales, transformed the Caribbean into a Jewish place (bound by location), and a Jewish space (bound by opportunity). ${ }^{18}$ Yet, only a few Jewish Sephardic colonists and merchants who circulated across cultural, linguistic, political, and geographical borders in the Atlantic left behind much in the way of writing. ${ }^{19}$ Fragments of the Sephardic Jews' transatlantic biographies can, however, be gleaned from a variety of sources. Among these are the various communal records such as the intraand inter-communal correspondence (copiador), the communal minute books (livros da nação), ${ }^{20}$ registers of births and deaths, hashkabah books (prayer of

16 See Adam Sutcliffe, "Ideas and Space: Heterodoxy, Circulation and Urban Life in the Western Sephardic Diaspora," unpublished manuscript, Hamburg 2005; id., "Jewish History in an Age of Atlanticism," in Atlantic Diasporas, Jews, Conversos, and Crypto-Jews in the Age of Mercantilism, 1500-180o, ed. Richard L. Kagan and Philip D. Morgan (Baltimore: The Johns Hopkins University Press, 2009), 28-29.

17 Sutcliffe, "Ideas and Space."

18 Julia Brauch, Anna Lipphardt and Alexandra Nocke, eds., Jewish Topographies: Visions of Space, Traditions of Place (Aldershot: Ashgate, 2008).

19 David de Ishac Cohen Nassy, Essai historique sur la colonie de Surinam (Amsterdam: S. Emmering, 1968); Jonathan I. Israel, "The Dutch Jewish Enlightenment in Surinam, 1770-180o," in The Religious Cultures of Dutch Jewry, ed. Yosef Kaplan and Dan Michman (Leiden, Boston: Brill, 2017), 183-206; Gérard Nahon, "Nefusot Yehuda (Bayonne) et Beraha ve-Shaom (Surinam). Livres et lecture au XVIII ${ }^{\text {ème }}$ siècle," in A Sefardic Pepper-Pot in the Caribbean, ed. Studemund-Halévy (Barcelona: Tirocinio, 2016), 362-428.

20 We know of six thousand despachos in the years from 1615 to 1759 and the destination is known for more than four thousand, see Tirtsah Levie Bernfeld, Poverty and Welfare Among the Portuguese Jews in Early Modern Amsterdam (Oxford: Littman Library of Jewish Civilization, 2012), 47. The minute books of Amsterdam and Hamburg contain innumerable references to voluntary or involuntary emigration to the British and Dutch colonies. For Hamburg, see Alfonso Cassuto, "From the Old Minute Book of the Sephardic 
repose), lists kept by ritual circumcisers (mohalim), marriage contracts (ketubot), final wills and testaments, ${ }^{21}$ bequests, family trees, coats of arms, portraits of Sephardic rabbis and merchants, passenger lists, and hand-written genealogies in Mahzorim (prayer books) and the various documentation left by the many itinerant hakhamim and hazzanim, merchants and physicians who island-hopped between the Jewish communities in the Caribbean. ${ }^{22}$ Colonial proceedings and records comprise another important primary source of information, as do also the denunciation reports and Inquisition protocols containing (mini-) egodocuments. ${ }^{23}$ Unfortunately, autobiographical life stories or ethical wills, which can teach us much about the past, are rare, ${ }^{24}$ and very few

Congregation, of Hamburg, Relating to Jews of Barbados," Publications of the American Jewish Historical Society 32 (1931):114-15; Studemund-Halévy, "Across the Waters. Sephardic Pioneers from Hamburg in the Caribbean," in A Sefardic Pepper-Pot in the Caribbean, ed. Studemund-Halévy (Barcelona: Tirocinio, 2016), 150-209. For Amsterdam, see Levie Bernfeld, Poverty and Welfare Among the Portuguese Jews in Early Modern Amsterdam; id., "Exit Amsterdam: Poor Portuguese and Caribbean Horizons," in Studemund-Halévy, $A$ Sefardic Pepper-Pot, 210-29; for London, see Julia R. Lieberman, "New Practices of Sedaca," in Charity on Jewish, Christian, and Islamic Traditions, ed. Julia R. Lieberman and Michal Jan Rozbicki (Lanham: Lexington Books, 2017), 105-29.

21 See, for example, Samuel Oppenheim, "List of Wills of Jews in the British West Indies prior to 180o," in Publications of the American Jewish Historical Society 32 (1931): 55-64; D.M. Zielonka, "A Study of the Life of the Jews in Jamaica Reflected in Their Wills, 1692-1798," MS SC-13489 (term paper, AJA Cincinnati, 1963); Joanne McCrea Sanders, ed., Barbados Records. Wills and Administrations, 3 vols. (Houston: Sanders Historical Publications, 19791981); see also Karl Watson et al., The Wills of the Jews, 1685-1847 (Bridgetown, n.p., n.d.). An innovative source are the selected documents (letters, wills, epitaphs, religious discourses, and literary works about Jewish Life in the Americas), edited by Michael Hoberman, Laura Leibman and Hilit Surowitz-Israel, Jews in the Americas, 1776-1826 (London: Routledge, 2018).

23 A rich source, to date not thoroughly evaluated, are the trials of the Venetian Inquisition, masterfully edited in 14 volumes, by Pier Cesare Ioly Zorattini, Processi del Santo Uffizio di Venezia contro Ebrei e Giudaizzanti, 1608-1632 (Florence: Olschki, 1999); Ioly Zorattini, L'identità dissimulata (Florence: Olschki, 200o); "EPIDAT-Datenbank zur jüdischen Grabsteinepigraphik. Inventarisierung und Dokumentation historischer jüdischer Friedhöfe," in Wenn das Erbe in die Wolken kommt. Digitalisierung und kulturelles Erbe, ed. Eckhard Bolenz, Lina Franken, Dagmar Hänel (Essen: Klartext, 2015), 161-68, 195-248. See, for example, the fascinating story of the Old Christian Fernando Almeida Pereira, who embraced the Jewish faith in Hamburg, Michael Studemund-Halévy, "Les aléas de la foi. Parcours d'un jeune Portugais entre église et synagogue," in Memoria. Festschrift für Michael Brocke, ed. Birgit Klein (Berlin: Metropol, 2005), 363-82; id., "Rückkehr mit Widerruf. Ein junger Portugiese zwischen Kirche und Synagoge," in Tribunal der Barbaren? Deutschland und die Inquisition in der Frühen Neuzeit, ed. Albrecht Burkardt and Gerd Schwerthoff (Konstanz and Munich: UVK Verlagsgesellschaft, 2012), 255-75.

24 Israel Abrahams, ed., Hebrew Ethical Wills (Philadelphia: Jewish Publication Society of America, 1926). 
egodocuments ${ }^{25}$ or biographical sketches have come down to us and can be used by social historians interested in the daily life of these tropical exile Jews. ${ }^{26}$ Another rich primary source is the numerous Jewish graveyards across the Caribbean with their more than ten thousand Jewish gravestones containing important first-hand information about deceased members of the Sephardic communities of the Jewish Atlantic. The gathering and collating of all these sources into a prosopographical database is a project currently being developed in the Hamburg-based Institute for the History of the German Jews.

In the last twenty years, there has been a steady stream of important monographs, ${ }^{27}$ collections of essays, ${ }^{28}$ a broad range of research projects, exhibitions, ${ }^{29}$ and specialized conferences on the subject of the Jewish Caribbean, delineating geographic and thematic areas for further exploration and stimulating an important interdisciplinary discussion about Jewish life in the New World in the first three centuries of European colonialism. This burgeoning interest has led to some Sephardic places being considered for the UNEsco World Heritage list, such as the Jodensavanne (Jewish savanna) in Suriname and the Jewish cemetery at Cassipora, ${ }^{30}$ the oldest extant in the Americas and a reminder of the pioneers of American Judaism. Beth Haim cemetery on the island of Curaçao has already been designated a UNESco World Heritage site. ${ }^{31}$

25 Avriel Bar-Levav, "When I Was Alive. Jewish Ethical Wills as Egodocuments," in Egodocuments and History. Autobiographical Writing in Its Social Context since the Middle Ages, ed. Rudolf Dekker (Hilversum: Verloren, 2002), 45-59.

26 See, for example, the three autobiographical texts in Ronnie Perelis, Narratives from the Sephardic Atlantic. Blood and Faith (Bloomington: Indiana University Press, 2016).

27 Zvi Loker, Jews in the Caribbean. Evidence on the History of the Jews in the Caribbean Zone in Colonial Times (Jerusalem: Misgav Yerushalayim, 199); Mordechai Arbell, The Jewish Nation of the Caribbean (Jerusalem and New York: Geffen, 2002); Jonathan I. Israel, Diasporas within a Diaspora:Jews, Crypto-Jews, and the World of Maritime Empires, 15401740 (Leiden: Brill, 2002).

28 Kagan and Morgan, Atlantic Diasporas; Paolo Bernardini and Norman Fiering, eds., The Jews and the Expansion of Europe to the West, 1450-1800 (New York: Berghahn, 2001); Jane S. Gerber, ed., The Jews in the Caribbean (Oxford: The Littman Library of Jewish Civilization, 2014); Arthur Kiron, ed., Constellation of Atlantic Jewish History, 1555-1880 (Philadelphia: University of Pennsylvania Press, 2014); Studemund-Halévy, ed., A Sefardic Pepper-Pot; Stanley Mirvis, Jewish Treasures of the Caribbean. The Legacy of Judaism in the New World (Atglen: Schiffer Publishing, 2016).

29 Julie-Marthe Cohen, ed., Joden in de Cariben (Zutphen: Walburg Pers., 2015).

30 http://whc.unesco.org/en/tentativelists/1083/.

31 The nomination of the Jewish Cemetery Hamburg-Altona as a World Culture Heritage site stresses the importance of the Sephardic cemetery and Hamburg's importance in the Jewish and Sephardic world, see Michael Studemund-Halévy, "Portuguese Jewish Cemetery," in Nomination for the UNESCO World Heritage List. Nomination Dossier: The 
These cumulative efforts have spurred the creation of a "Relational Prosopographical Database of the Sephardic Atlantic."32 Prosopography is the study of a group through the collective study of its members. The relational database will contain information about all the members of the Sephardic nation who lived during any period of history in the Caribbean and will include the name, sex, date of birth and death, religion, marital status, social and economic class, profession, and offices held for every individual who was a part of one of the Jewish communities. The database will be a collective biography of the Sephardic Jews in the Caribbean, a community that was perpetually in flux, and whose written and material legacy is dispersed in archives and libraries all over the world. The database will be freely accessible to researchers and the broader public on the worldwide web. ${ }^{33}$

The Caribbean Jewish cemeteries constitute a rich primary source for the study of local and global Sephardic history. To date, most of the Caribbean Jewish cemeteries have been scientifically documented. ${ }^{34}$ Using the information

Jewish Cemetery Hamburg-Altona, ed. Agnes Sommer (Hamburg: Free Hanseatic City of Hamburg. Ministry of Culture, 2017).

32 Since the mid-1980s, the non-profit BSRP has spearheaded a series of cultural heritage initiatives in a city block that is part of the UNESCO-designated World Heritage site of historic Bridgetown and its Garrison. These include the restoration of the Nidhe Israel Synagogue (1985); conservation of the adjacent Jewish cemetery (2001); establishment of the Nidhe Israel Museum (2008); unearthing of the mikveh (2009), etc. The last phase of these projects, just completed in November 2016, has been the redevelopment of the whole block surrounding the synagogue. This ambitious undertaking has breathed new life into a series of architectural gems, such as the old Firehouse and Weights and Measures building, and artisans' workshops, and created amenities for locals and tourists alike (such as a cafe and an art gallery). The records of the Bridgetown Synagogue Restoration Project (BSRP) have now been fully processed and digitized. The major part of the collection has been uploaded to the Digital Library of the Caribbean (dLOC) and can be freely viewed online. See, for example, Digitizing Caribbean Jewish Documentary Heritage The Barbados Synagogue Restoration Project (http://dloc.com/p1_nisyn); Digital Library of the Caribbean (http://dloc.com); A Nação: Prosopography of the Portuguese Jewish Nation, 1599-180o (http://nacao.weebly.com/about.html). See also Amanda S. Levi, "Linked Sephardim: A Prosopography of the Sephardic Community of the Island of Barbados, West Indies" (unpublished manuscript).

33 The following three websites are possible sites to host the database: A Nação:Prosopography of the Portuguese Jewish Nation, 1599-180o, the Digital Library of the Caribbean and more particularly, the Jewish Diaspora Collection that is part of the dLOC.

34 With the exception of Tobago, Aruba, St. Eustatius, St. Thomas and St. Croix. For the Sephardic cemeteries, see Surinam: Aviva Ben-Ur and Rachel Frankel, Remnant Stones: The Jewish Cemeteries and Synagogues of Suriname: Essays (Cincinnati: Hebrew Union College, 2012); Barbados: Eustace M. Shilstone, Monumental Inscriptions in the Burial Ground of the Jewish Synagogue at Bridgetown, Barbados (New York, n.p., 1956); Vere Langford Oliver, Monumental Inscriptions: Tombstones of the Island of Barbados (San 
collected from tombstones, historians, social historians, art historians, and genealogists will be able to trace the everyday life of the Sephardic communities in the Caribbean, reconstruct family relationships and population movement, and demonstrate the global nature of the Sephardic Nação and the significance of ethnicity and kin in the development of cross-Atlantic trade relationships.

Gravestones are unique lenses through which the historical developments in a given community become visible. The inscriptions are, as David Malkiel so aptly put it, "snapshots of a society's social and cultural proclivities at particular moments in time." ${ }^{35}$ For researchers focusing on the socio-economic history of a city, region or community, cemeteries are a rich primary source. Beyond the iconographical elements of the tombstone decoration and the spatial elements of the burial ground itself, a tombstone epitaph provides important biographical and prosopographical information. Usually the text is concise, but some provide a detailed accounting of the deceased's life, religious role (rabbi, hazan [cantor], teacher; ${ }^{36}$ or profession (e.g., merchant, trader, shop owner, slave

Bernardino: Borgo Press, 1995); Richard Barnett, "Tombstones in Barbados," Tesoro de los judíos sefardíes 2 (1959): 45-46; Karl Watson, "New Jewish Tombstones Revealed: Additions to Shilstone's Record of Sephardic Tombstones in Bridgetown, Barbados," Journal of the Barbados Museum \& Historical Society 62 (2016): 152-61; Michael Studemund-Halévy, "New Jewish Epitaphs from Bridgetown, Barbados" (forthcoming); Curaçao: Isaac S. Emmanuel, Precious Stones of the Jews of Curaçao: Curaçao Jewry 1656-1957 (New York: Bloch, 1957); Nevis: Michelle M. Terrell, The Jewish Community of Early Colonial Nevis: A Historical Archaeological Study (Gainesville: University of Florida Press, 2005); Jamaica: Richard D. Barnett and Philip Wright, The Jews of Jamaica. Tombstone Inscriptions, 16631880 (Jerusalem: Ben-Zvi Institute, 1997); Marilyn Delevante, The Knell of Parting Day. A History of the Jews of Port Royal and the Hunt's Bay Cemetery (Kingston: n.p., 2008); St. Thomas: Julius Margolinsky, 299 Epitaphs on the Jewish Cemetery in St. Thomas, W.I., 1837-1916 (Copenhagen: n.p., 1957); St. Croix: Bernard Heller, Epitaphs in the Jewish cemeteries at Christianstad, St. Croix (unpublished manuscript 1958); Jacob Robles, "Names on Stones in Savan Cemetery, Charlotte Amalie, St. Thomas Burials, So Far Located" (unpublished manuscript 1972).

35 David Malkiel, Stones Speak—Hebrew Tombstones from Padua, 1529-1862 (Jerusalem: Ben Zvi Institute, 2014), 1.

36 The only multi-scene panel found in the cemetery in Barbados includes a depiction of a stylishly dressed ba'al tokeah (shofar blower). Could it be a portrayal of an actual individual, namely a portrayal of the venerated hakham, ribi ("rabbi teahe"), scribe, mohel (ritual circumciser), and shofar blower? The beautiful and lavishly decorated gravestone for $\mathrm{Me}(\mathrm{h})$ ir Cohen Belinfante, who passed away $175^{2}$ in Barbados, is an elaborate life cycle carved in Hebrew, Portuguese and English along the borders and depicting the various professions of the deceased. At the top, the hands in a priestly blessing symbolize his being a Kohen; at the bottom are three panels that show aspects of his profession as a rabbi, hazan and mohel. The first panel shows a crown with the hands in the clerical benedictional gesture of a Kohen, the descendant of the high priest Aaron. In the second 
owner, physician). ${ }^{37}$ An epitaph can provide information about the individual and his or her family's lineage, ethnic origins, religion, and religious attitudes, ${ }^{38}$ birthplace (important for studying geographical spread), facts about their life and cause of death (slave uprisings, ${ }^{39}$ crime, death at sea), peregrinations, ${ }^{40}$ marital status, transnational marriages, ${ }^{41}$ number of children, social status (attachment to society and culture), ethnic and kinship connections, ${ }^{42}$ inclusion and exclusion in colonial societies (guilds), magnitude of wealth, distribution of gender, ${ }^{43}$ profession, honorific titles, names (Jewish and/or non-Jewish), ${ }^{44}$

panel, the Hakham Belinfante is depicted in fashionable gentleman's clothing of the day (Rococo), blowing a shofar, one of his duties as hazan, and from biblical times associated with messianic redemption and eschatology — the end of time. This panel reflects the impulse among Sephardim from Venice and Amsterdam to preserve a portrait of the venerable rabbi for "good memory," as an act of respect and a way of safeguarding his image in their minds. The third panel illustrates his profession as sofer (scribe, designation for a rabbinical scholar), commemorated by a hand holding a quill pen. The fourth panel shows the tools of a mohel which he practiced (knife, shield, scissors, pincers, forceps, probe, wine cup, and flacons for substances).

37 Jewish merchants and traders played an important role in the Caribbean, a fact proudly reflected in numerous epitaphs.

38 The Maduro Stichting in Curaçao encompasses an extensive collection of genealogical trees, for example, of the families Abudiente, Brandao, Jessurun, Namias de Crasto, etc. Such resources can be found in the databases of SephardicGen (http://www.sephardic gen.com/), or providers such as Ancestry.com.

39 Suriname experienced repeated and violent clashes during the slave uprisings in the Caribbean. These uprisings were often mentioned on the tombstones, see Michael Studemund-Halévy, "Epitaphs in Blood. Crime and Punishment in Sefardic Tombstones," in Jahrbuch Zentrum Jüdische Studien Berlin-Brandenberg 4 (forthcoming). See, for example, Surinam: Sa / do yncurtado / mancebo David Rods / Monsanto que foy / matado / por os crueys negros [...]; Jamaica; $\mathrm{S}^{\mathrm{a}}$ / do manso virtuozo e benigno / Samuel de Lucena que por / mão do cruel Barbaro homecida / foy derramado seu inocente / sangue[...].

40 See, for example, the "Hotten's List," New York 1931, 438-450, see also www.yale.edu/glc/ archive/116o.rtf (accessed 20 March 2014), "English-America: The Voyages, Vessels, People, and Places."

41 A perusal of the Amsterdam marriage contracts (ketubot) shows that among the 15,238 couples that married in that city between 1598 and 1811 there were numerous marriages with brides and grooms from Brazil and the Caribbean: St. Marten: 1; Guyana and St. Croix: 2 each; St. Eustatius and Jamaica: 4 each; Suriname: 19; Brazil: 44, and Curaçao: 48, see Dave Verdooner and Harmen Snel, eds., Trouwen in Mokum: Jewish Marriage in Amsterdam, 1598-1811, 2 vols. (The Hague: Koninklijke Bibliotheek, s.a.).

42 Karl Watson, "Shifting Identities: The Role of Religion, Race and Creolization among the Sephardic Jews of Barbados, 1654 to 1990," in The Jews in the Caribbean, ed. Jane S. Gerber (Oxford: The Littman Library of Jewish Civilization, 2014), 195-222.

43 Since cemetery plots had to be bought for women as well as men, death information tends to be more complete than birth or death registers where entries for women were sometimes recorded in a very incomplete manner.

44 The name change can be a potential problem in constructing networks of family relationships or migrations. 
disambiguity of names, ${ }^{45}$ naming practices (naming the child after a living person), ${ }^{46}$ name change as a result of sickness (rogativa). ${ }^{47}$ The language choice may be testimony to the deceased's peripatetic life as a trader, foreigner, or exile (Hebrew, Spanish, Portuguese, Dutch, English). Epitaphs containing compositions of languages (monolingual, bilingual and polyglot epitaphs), ${ }^{48}$ poetry (rhetorical and poetical devices, gematria poems), and arrangements of letters into acrostics, anagrams, palindromes, pattern poems, mnemonic strings of letters or cryptograms, letter manipulation and permutation, translations (from Hebrew into English, from Portuguese into Hebrew, etc.), biblical and Talmudic quotations, rhetorical formulae and literary devices (such as speaking epitaphs), ${ }^{49}$ are prime sources for studying the community's cultural, social, and literary history, as are the richly decorated gravestones containing a profusion of visual images (Jewish vs. pagan symbols), memento mori symbols (skull, crossed bones, hourglass, butterfly, skeleton, karet [lit. cut down, a hand appearing from the clouds fells the tree of life]), ${ }^{50}$ family trees, biblical

45 Due to naming conventions, many of the individuals in the post-exile Sephardic communities bear more than one name (as a Jew, as a Christian, as a Marrano, etc.).

46 In eighteenth-century Surinam, for example, ninety percent of recorded Jewish births followed this pattern, see Erik R. Seeman, Death in the New World. Cross Cultural Encounters, 1492-180o (Philadelphia: University of Pennsylvania Press, 2010), 249.

47 See, for example, the epitaphs from Barbados for: Abraham Lindo, died 1763: "en su Enfermedad su nombre fue Mudado en Jahacob"; Jacob Haim Carvallo, died 1749: "o cuio nombre fue Mudado en Moseh"; Abraham Pinheiro, died 1755, "que en Su Enfermedad fue mudado su nombre en Jehosua"; Semuel Massiah, died 1751: "que fue mudado Su nombre en Mosseh"; Abraham Hizkiau Valverde, died 1746, reads: "que fue Mudado su Nombre en Ysrael y Despues en Hisquija."

48 The use of Hebrew, Portuguese, Spanish, and later Dutch, English, and Papiamento by Sephardim (and Ashkenazim) in colonial America reflects the regional varieties and the linguistic, cultural, and social status of these languages: high vs. low, spoken vs. written, de facto vs. de jure, holy vs. secular.

49 Curaçao: "Los vivientes que aqui pasaren / y la lectura desta tomaren se desengañen / y se

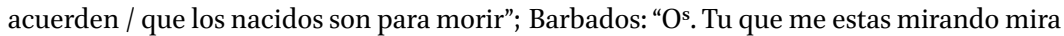
bien / Que bives bien por que no sabes la hora quando / quando te veras a Sy también"; Jamaica: "Porque assi de mi tumba te desvias / moria sin aplicar tu pensamiento [...]; se precuras saber o caminhante / quem se guarda nesta sepoltura [...]." On the dialogue between the deceased and the passer-by, a well-known motif in the Hebrew-Spanish and post-exile Sephardic literature in the Western and Eastern Sephardic Diaspora, see Michael Studemund-Halévy, "Wanderer der Du hierher kommst, lobe ihre Erinnerung. Der Dialog mit dem Verstorbenen in sefardischen Grabinschriften (forthcoming); see also Carsten L. Wilke, "Dialogue of the Dead. Talking Epitaphs by Sephardi and Ashkenazi Rabbis of Hamburg", in Zutot 5, no. 1 (2008): 61-74.

5o The epitaph for Jacob Haim Carvallo from Barbados reads: SEPULTURA / Del Bienaventurado / Jaacob Haim Carvallo / o cuio Nombre fue Mudado / en Mosseh que Fallecio / a los 48 Años de Su edad / en 26 de Tamuz Ano de / 5509 o que Corresponde / a 30 de Junio de 1749. For the Sephardim, the Tree of Life was a widely known Jewish 
narratives (binding of Isaac; Joseph in the pit; David playing the harp; Daniel in the lion's den; Jacob and Rachel, Abigail and David, ${ }^{51}$ depictions of God, ${ }^{52}$ scenes of illness and death, ${ }^{53}$ angels, cherubim, putti, animals and flowers, ${ }^{54}$ lettering (raised versus engraved letters), and the space of the grave itself (individual grave, family grave, grave of honor). Also the quality of stone (stones for Curaçao, Surinam, and for Barbados, for example, were invariably imported from Amsterdam [blue stones], Italy [marble stones], and North America [porphyry], ${ }^{55}$ reveals information about the deceased, the community, and the

symbol and a symbol of messianic hope in the seventeenth century. In Surinam, at least 57 of 134 stones $(42 \%)$ that bear iconography display the theme of karet, and in Barbados at least 66 of 374 stones (17.64\%) display this motif (30 for men, 29 for women). While Altona possesses a relatively higher percentage of illustrated stones $(30 \%)$ than Suriname $(8.12 \%)$, the karet image appears almost twice as often. The Tree of Life, generally symbolized by biblical cypress and palm (in Hamburg and Amsterdam), or tropical pine tree and coconut tree (in Barbados), demonstrates in the Caribbean an affinity with the place of origin of the decedent, see Ben-Ur and Frankel, Remnant Stones: Epitaphs: Cassipora cemetery: 8 karet scenes; Jodensavanne: 16 karet scenes; Sephardi cemetery Paramaribo: 22 karet scenes; Ashkenazi cemetery Paramaribo: 12 karet scenes. As in Altona, karet scenes in Suriname decorate more often the gravestones of women than men.

51 Sephardim of the Western Sephardic diaspora, embracing the iconographic traditions of the lands in which they lived, seem to have exulted in their ability to proclaim to the world their ancestral faith and their varied bequests, see Michael Studemund-Halévy, "The Persistence of Images: Reproductive Success in the History of Sephardi Sepulchral Art," in The Dutch Intersection, ed. Yosef Kaplan (Leiden: Brill, 2008), 123-147; id., "More than Images"; Karl Watson, "The Iconography of Gravestones in the Jewish Graveyard, Bridgetown, Barbados," Journal of the Barbados Museum \& Historical Society 50 (2005): 195-212; Natalie Zeldin, "Skulls, Shields and Narratives," (unpublished manuscript); id., "Imaging Death: Sepulchral Iconography in the Koenigstrasse Cemetery," (unpublished manuscript); Seeman, Death in the New World, 253.

$5^{2}$ See Studemund-Halévy, "More than Images," 429-88.

53 Putrid fever was frequent in the Caribbean, see the epitaph of Samuel Hoheb Brandon, died 1793 in Bridgetown, Barbados: "Here lies the Body of Mr SAMUEL HART / Merch" who died on the 29th day of Tisry / which corresponds with the 15th Day of / October 1773 Aged 53 Years 9 months and 2 / days of a Putrid Fever in Bridgetown / Barbados."

54 Elias Valverde, died on 22 August 1725 in Barbados. His epitaph reads: "SA / Do Anjo ELIAV FILHO / de DAVID \& SIMHA / ABIGAIL VALVERDE / que Faleleceu em do / mingo 24 de Elul / Ano 5485 / de Idade de 37 Meses."

55 Many Jews in the colonies imported tombstones from Amsterdam, London, and Venice. Some stones reveal that gravestones also traveled between the colonies, see for example the tombstone of Samuel Hart, a member of an important Newport Jewish family, died in Barbados of a purtrid fever. This tombstone was recognized by Laura A. Leibman as the work of Williams Stevens, a famous carver from Newport, Rhode Island. Many of Newport's early Jews came via Barbados, and throughout the eighteenth century exchange between Newport and Barbados was a crucial trade route; see also Shilstone, 


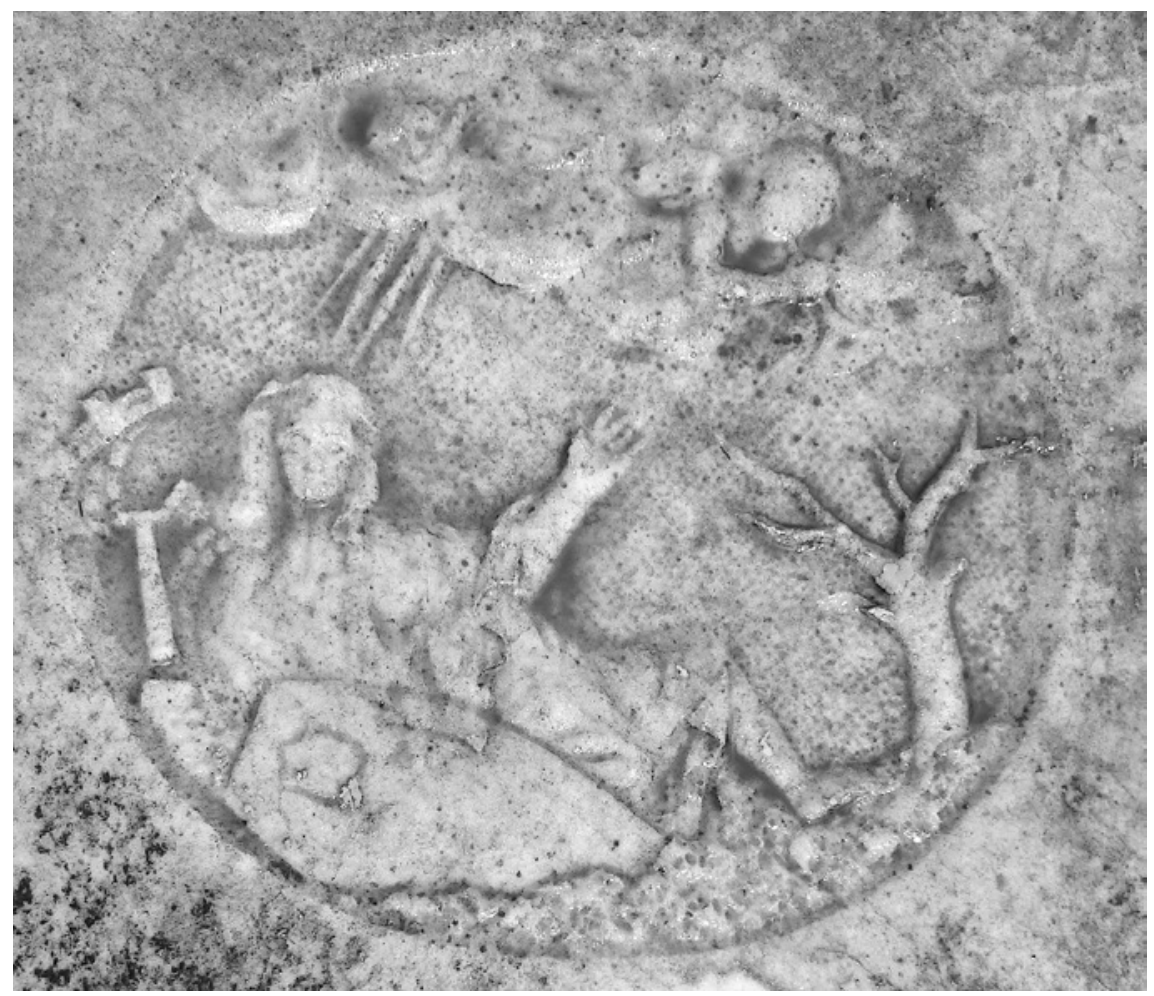

FIGURE 20.1 Gravestone of Bella Barrow, wife of Simon Barrow, died 1 October 1773, aged 53 years, in Barbados, detail PHOTO: MICHAEL STUDEMUND-HALÉVY, BARBADOS, 2017

stonemason, ${ }^{56}$ and more. All the minor and major themes of Jewish Atlantic history-migration and peregrinations, circum-Atlantic world, Iberian roots, re-Judaization, ethnicity, circulation of ideas, European and American identity, Sephardim and Ashkenazim, Jews and Blacks—unfold within in this corpus (Figs. 20.1, 20.2. 20.3 and 20.4).57

A tombstone's epigraphy and iconography stand in relation to the specific cemetery in which it is found, but also to neighboring and even distant cemeteries, often across borders, and oceans. All the minor and major themes of

Inscriptions, xxviii; Emmanuel, Precious Stones, 129; Ben-Ur and Frankel, Remnant Stones. Essays, 76-81.

$5^{6}$ The artist or stonecutter, who carved and created the gravestones, generally did not sign his work.

57 Aviva Ben-Ur, "Atlantic Jewish History. A Conceptual Reorientation," in Constellation of Atlantic Jewish History, 1555-1880, ed. Arthur Kiron (Philadelphia: University of Pennsylvania Press 2014), 25-46. 


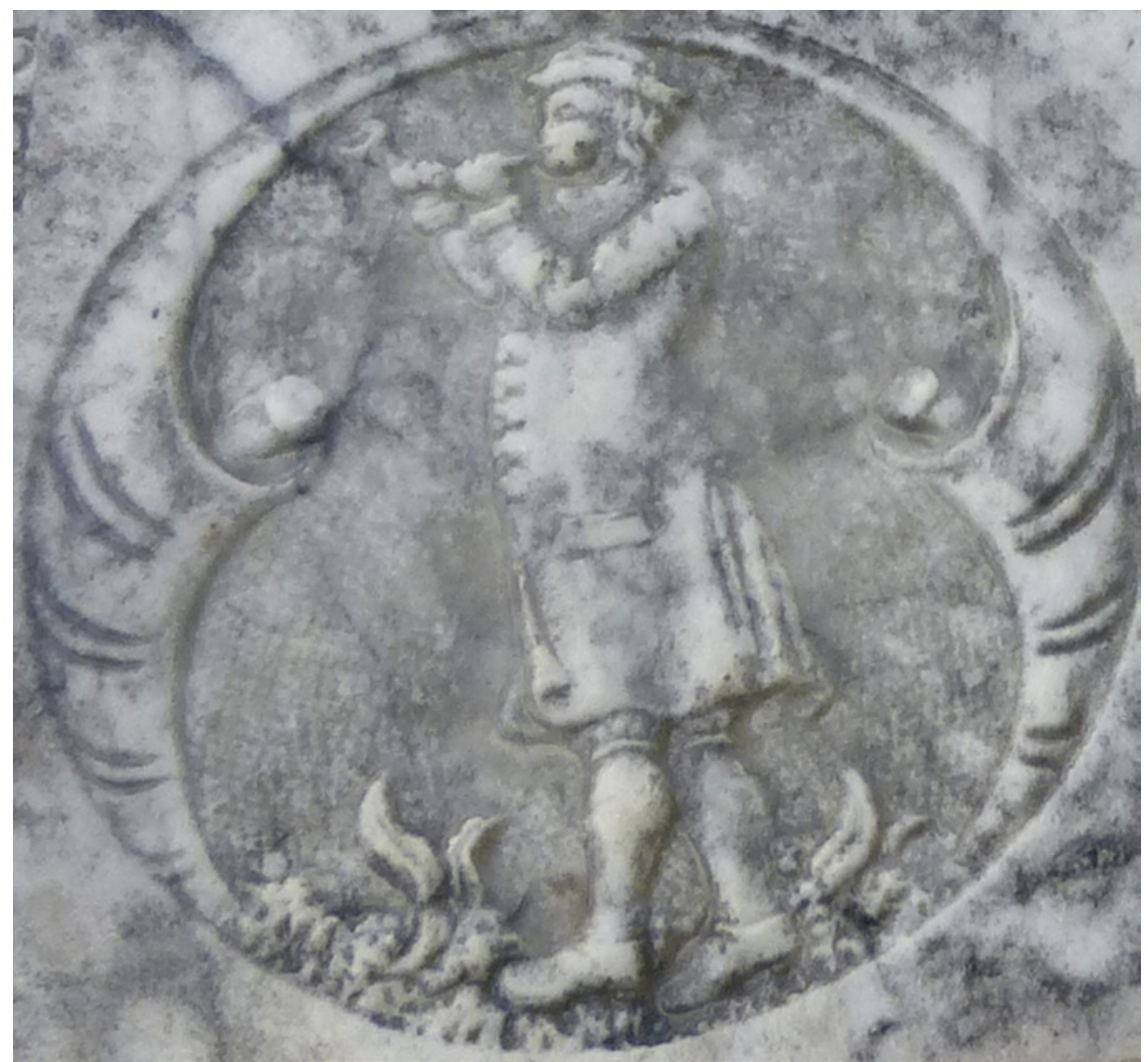

FIGURE 20.2 Gravestone of Hakham Mehir Cohen Belinfante, died 25 September 1752, aged 48 years, in Barbados, detail

PHOTO: MICHAEL STUDEMUND-HALÉVY, BARBADOS, 2017

Jewish Atlantic history-migration and peregrinations, re-Judaization, Iberian roots, race and ethnicity, ${ }^{58}$ circulation of ideas and knowledge, European and American identity, relations between Sephardim and Ashkenazim, between Jews and Blacks - unfold within this corpus. ${ }^{59}$ And because practically all Sephardic communities, whether in Europe or the Caribbean, were interconnected by close family, religious and economic ties, the standardization of Sephardic sepulchral art and language can provide information not only about globalization, both economic and cultural, but also about inter-Caribbean and international trade relations and family networks. A methodological study of

$5^{8}$ See Alan F. Benjamin, Jews of the Dutch Caribbean. Exploring ethnic identity on Curaçao (London: Routledge, 2002).

59 Ben-Ur, "Atlantic Jewish History. A Conceptual Reorientation," 25-46. 


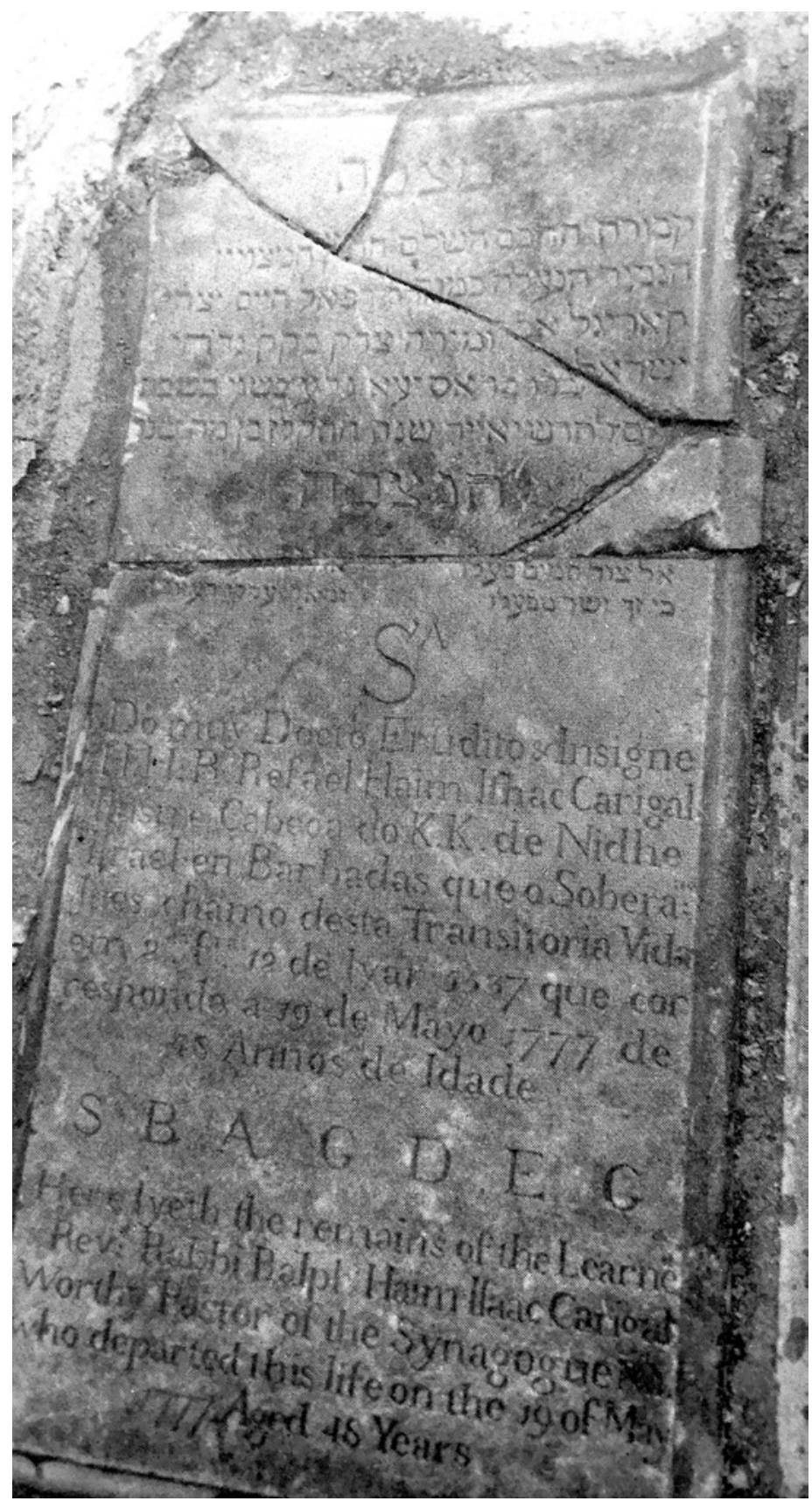

FIGURE 20.3 Gravestone of Rabbi Refael Haim Ishac Carigal, died 19 May 1777, aged 48 years, in Barbados PHOTO: MICHAEL STUDEMUND-HALÉVY, BARBADOS, 2017 


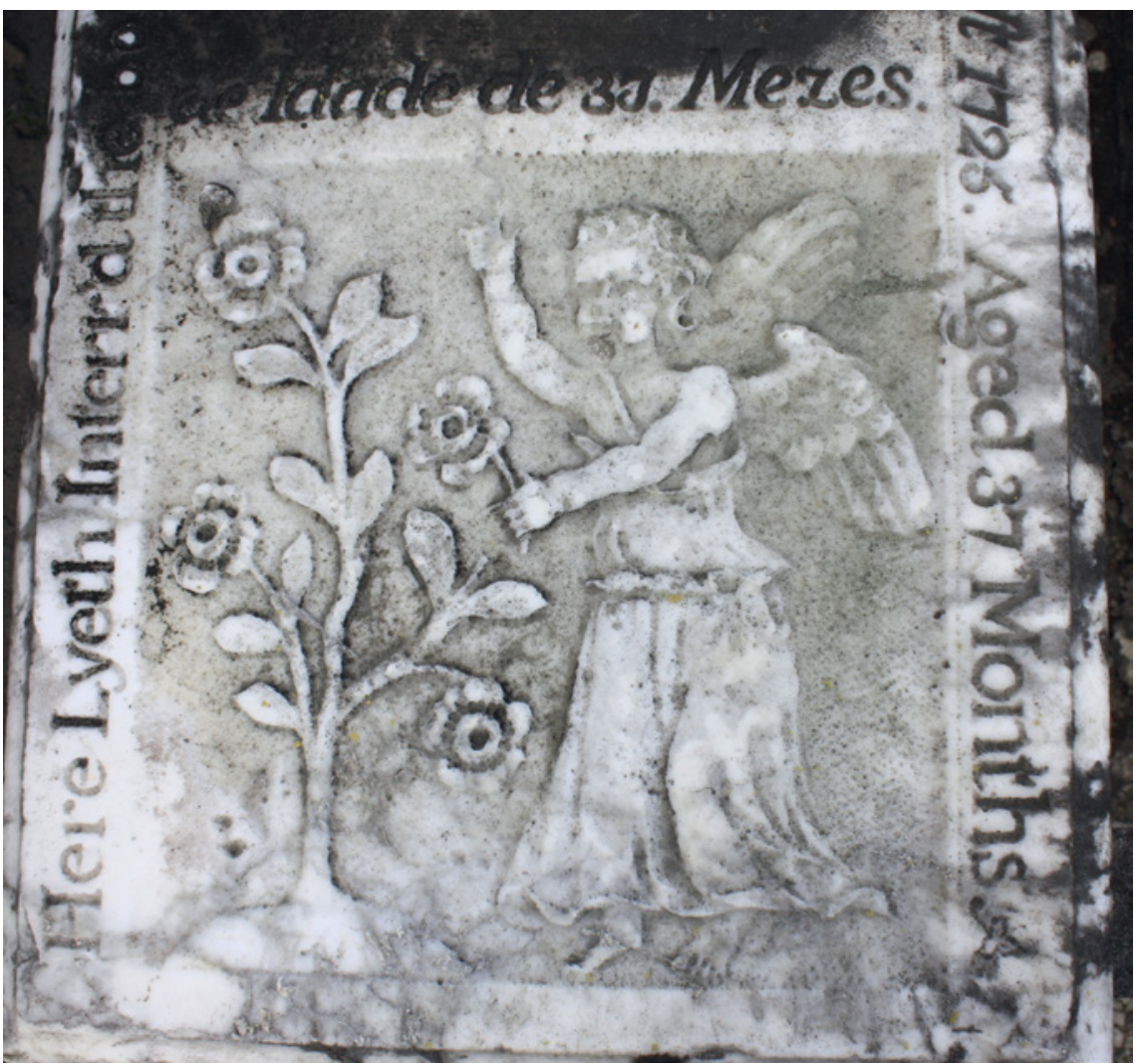

FIGURE 20.4 Gravestone of Elias Valverde, son of David and Simha Valverde, died 22 August 1725, aged 37 months, in Barbados, detail

PHOTO: MICHAEL STUDEMUND-HALÉVY, BARBADOS, 2017

the documentation of the lived experiences of real people, their loves, their suffering, would at long supplant random biographies with solidly established "human truths" and "human belongings."

A cemetery's spatial aspects - the gravestones lying next to and behind one another, the rows and fields - what binds the gravestones in situ and constitutes the cemetery as an ensemble of tombstones, can also yield important information. Placement in a burial compound is rarely accidental. ${ }^{60}$ The database will have an interactive location tool for examining the spatial layout of the gravestones that will be able to highlight regularities and patterns such as rows or groups of gravestones that display the same symbol or a family-specific

6o Hakham Mehir Cohen Belinfante died on 25 September $175^{2}$ in Barbados. 
symbol that can be found in a number of Caribbean cemeteries or in cemeteries in Amsterdam, Hamburg, or Glückstadt.

The database will be reachable through a website that will provide access to rich, structured, biographical information relating to the broadest possible number of recorded Sephardic Jews and New Christians in the Caribbean from the mid-seventeenth to the late nineteenth century, drawing initially on primary archives in the Caribbean. This will gradually be enriched by archives from other former Sephardic centers such as Amsterdam, London, and Hamburg. ${ }^{61}$ The database will also be enhanced and refined by associated research projects that will utilize (and in the process, contribute to) the database. ${ }^{62}$ This will require biographical data for large numbers of individuals, and the information available for many individuals may be quite limited, and consist of scattered references in different documents. These will need to be connected and recorded in databases in order to facilitate investigation of larger patterns. In accordance with the model presented by the well-known epigraphic database EPIDAT, all data relating to the Sephardic cemeteries in the Caribbean will be entered into the E PIDAT Cemetery Databases. ${ }^{63}$ Using the programming language TUSTEP and a special EDV program, a full-text search in Hebrew, Portuguese, Spanish, English, Dutch, and German is possible. In addition, there are text-visual levels of documentation (time-based, locationbased, index-based, map-based, full-text-search) as well as the provision of options for detection of biblical quotations, parallel passages, iconography, and rough draft translation of a large number of fixed formulae. Symbols and dated headstones are visualized in the spatio-temporal interface of the

61 Project Relations in Space-Visualization of Topological Microstructures is working on the visualization of cemeteries, including the Jewish cemetery in Hamburg-Altona, see Tobias Arera-Rütenik andThomas Kollatz, "Interdisziplinäre Perspektiven auf Grabmale und Visualisierung räumlicher Strukturen. Ergebnisse eines Projektes zu historischen jüdischen Friedhöfen," in Objekt und Schrift. Beiträge zur materiellen Kultur des Jüdischen, ed. Karin Keßler et al., Jüdisches Kulturerbe 1 (2016): 25-29; see also "Raum-Zeit-Analysen mit DARIAH-Geo-Browser und DARIAH-Datasheet-Editor," in Bibliothek-Forschung und Praxis. 40, no. 2 (2016): 229-33, https://www.degruyter.com/view/j/bfup.2016.40.issue-2/ bfp-2016-0032/bfp-2016-0032.xml?format=INT.

62 See, for example, the recently published online-edition Key Documents of German-Jewish History, developed by the Institute for the History of the German Jews <jewish-historyonline.net>.

63 This Database of Jewish Epigraphy presents the inventory, documentation and editions of epigraphical collections. Currently available online are 179 digital editions with 32,172 epitaphs (63,429 image files), see "EPIDAT-Datenbank zur jüdischen Grabsteinepigraphik. Inventarisierung und Dokumentation historischer jüdischer Friedhöfe," in Wenn das Erbe in die Wolken kommt. Digitalisierung und kulturelles Erbe, ed. Eckhard Bolenz et al. (Essen: Klartext, 2015), 161-68. 
DARIAH-DE Geobrowser Visualization of family relations using the XTripels webservice. With the aid of the EPIDAT database developed at the Duisburg Salomon Ludwig Steinheim Institute ${ }^{64}$ and the Excel Database SEFARAD at the Institute for the History of the German Jews in Hamburg, ${ }^{65}$ into which the epitaphs of all previously studied and published Caribbean Sephardic cemeteries will be entered in the coming years, relations between the Sephardic cemeteries in the Old World and New World can become searchable and visible.

The relational prosopographical database will be an important tool for untangling the complex history of the Jewish Atlantic and the stories and peregrinations of individuals and family networks that Atlantic history might have otherwise forgotten. ${ }^{66}$

\section{Websites and Databases}

A Nação: Prosopography of the Portuguese Jewish Nation, 1599-180o: http://nacao.weebly.com/about.html DIGITAL LIBRARY OF THE CARIBBEAN: http://dloc.com

Digitizing Caribbean Jewish Documentary Heritage: The Barbados Synagogue Restoration Project: http://dloc.com/p1_nisyn

Epidat: http://www.steinheim-institut.de/cgi-bin/epidat

Sefardat: http://www.jüdischer-friedhof-altona.de/sefardat.html

Unesco Tentativelists: http://whc.unesco.org/en/tentativelists/1083/

\section{Bibliography}

Abrahams, Israel, ed. Hebrew Ethical Wills. Philadelphia: Jewish Publication Society of America, 1926.

Arbell, Mordechai. The Jewish Nation of the Caribbean. The Spanish-Portuguese Jewish Settlements in the Caribbean and the Guianas. Jerusalem: Gefen, 2002.

Arera-Rütenik, Tobias and Thomas Kollatz, "Interdisziplinäre Perspektiven auf Grabmale und Visualisierung räumlicher Strukturen. Ergebnisse eines Projektes zu historischen jüdischen Friedhöfen." In Objekt und Schrift. Beiträge zur materiellen

\footnotetext{
64 http://www.steinheim-institut.de/cgi-bin/epidat.

65 http://www.jüdischer-friedhof-altona.de/sefardat.html.

66 See, for example, Karen Racine, and Beatriz G. Mamigonian, eds., The Human Tradition in The Atlantic World, 1500-1850 (Lanham: Rowman \& Littlefield Publishers, 2010).
} 
Kultur des Jüdischen. Edited by Karin Keßler et al. Jüdisches Kulturerbe 1 (2016): 25-29.

Bar-Levav, Avriel. "When I Was Alive. Jewish Ethical Wills as Egodocuments." In Egodocuments and History. Autobiographical Writing in Its Social Context since the Middle Ages. Edited by Rudolf Dekker, 45-59. Hilversum: Verloren, 2002.

Barnett, Richard D. "Tombstones in Barbados." Tesoro de los judios sefardíes 2 (1959): $45^{-46 .}$

Barnett, Richard D., and Philip Wright. The Jews of Jamaica. Tombstone Inscriptions, 1663-1880. Jerusalem: Ben Zvi Institute, 1997.

Baylin, Bernard. Concept and Contours. Cambridge, MA: Harvard University Press, 2005.

Ben-Ur, Aviva. "Atlantic Jewish History. A Conceptual Reorientation." In Constellation of Atlantic Jewish History, 1555-1880. Edited by Arthur Kiron, 25-46. Philadelphia: University of Pennsylvania Press, 2014.

Ben-Ur, Aviva, and Rachel Frankel. Remnant Stones: The Jewish Cemeteries and Synagogues of Suriname: Epitaphs. Cincinnati: Hebrew Union College, 2009.

Ben-Ur, Aviva, and Rachel Frankel. The Jewish Cemeteries and Synagogues of Suriname: Essays. Cincinnati: Hebrew Union College, 2012.

Benjamin, Alan F. Jews of the Dutch Caribbean. Exploring Ethnic Identity on Curaçao. London: Routledge, 2002.

Bernardini, Paolo and Norman Fiering, eds. The Jews and the Expansion of Europe to the West, 1450-180o. New York: Berghahn, 2001.

Birkle, Carmen, and Nicole Waller, eds. "The Sea is History." Exploring the Atlantic. Heidelberg: Winter, 2006.

Bowden, Martyn J. "Disasters, Revolutions, and Discriminations in an Era of Economic Depression, 1776-1795: The World of the Sephardic Jews of Bridgetown, Part 3," Journal of the Barbados Museum \& Historical Society 61 (2015): 1-81.

Bowden, Martyn J. "Houses, Inhabitants and Levies: Place for the Sephardic Jews of Bridgetown, Barbados 1679-1729." Journal of the Barbados Museum \& Historical Society 57 (2011): 1-53.

Bowden, Martyn J. "Levels Discrimination and the Making of the Swan District in Bridgetown 1725-1766: Place for the Sephardic Jews in Bridgetown, Barbados, Part 2." Journal of the Barbados Museum \& Historical Society 62 (2016):77-151.

Bowden, Martyn J. "Three Centuries of Bridgetown: An Historical Geography." Journal of the Barbados Museum \& Historical Society 49 (2003): 3-137.

Brauch, Julia, Anna Lipphardt, and Alexandra Nocke, eds. Jewish Topographies: Visions of Space, Traditions of Place. Aldershot: Ashgate, 2008.

Britt, Brian M., and Alexandra Cuffel. Religion, Gender, and Culture in the Pre-Modern World. New York: Palgrave Macmillan, 2015. 
Burkardt, Albrecht and Gerd Schwerthoff, eds. Tribunal der Barbaren? Deutschland und die Inquisition in der Frühen Neuzeit. Konstanz and Munich: UVK Verlagsgesellschaft, 2012.

Cassuto, Alfonso. "From the Old Minute Book of the Sephardic Congregation of Hamburg, Relating to Jews of Barbados," Publications of the American Jewish Historical Society 32 (1931): 114-15.

Cassuto, Isaac. "Aus dem ältesten Protokollbuch der portugiesisch-Jüdischen Gemeinde in Hamburg." Jahrbuch der Jüdisch-Literarischen Gesellschaft 6 (1908/1909): 1- 54; 7 (1909/1910): 159-210; 8 (1910/1911): 227-90; 9 (1911/1912): 318-66; 10 (1912/1913): 255-95; 11 (1916): 1-76; 13 (1920): 55-118.

Cohen, Julie-Marthe, ed. Joden in de Cariben. Zutphen: Walburg Pers, 2015.

Cohen Nassy, David de Ishac. Essai historique sur la colonie de Surinam: sa fondation, ses revolutions, ses progrès, depuis son origine jusqu'à nos jours [...] avec l'histoire de la nation portugaise. Amsterdam: S. Emmering, 1968.

Cwik, Christian. "The Rise of Jewish Merchants Capitalists in the Caribbean: The Triangulation of Barbados, Jamaica and Curaçao." In A Sefardic Pepper-Pot in the Caribbean. History, Language, Literature, and Art. Edited by Michael StudemundHalévy, 13-29. Barcelona: Tirocinio, 2016.

Delevante, Marilyn. The Knell of Parting Day. A History of the Jews of Port Royal and the Hunt's Bay Cemetery. Kingston: n.p., 2008.

Emmanuel, Isaac S. Precious Stones of the Jews of Curaçao: Curaçao Jewry 1656-1957. New York: Bloch, 1957.

Endelman, Todd M. The Jews of Britain, 1656 to 200o. Berkeley: University of California Press, 2002.

Farrar, P. A. "The Jews in Barbados." Journal of the Barbados Museum \& Historical Society 9 (1942): 131-32.

Gerber, Jane S., ed. The Jews in the Caribbean. Oxford: The Littman Library of Jewish Civilization, 2014.

Gonsalves de Mello, José A. Gente da Nação. Recife: Massangana, 1989.

Heller, Bernard. "Epitaphs in the Jewish Cemeteries at Christianstad, St. Croix." Manuscript, 1958.

Heller, Reginaldo. "Diáspora Atlântica. A Nação Judaica no Caraibe, Séculos XVII e XVIII." PhD diss., Universidade Federal Fluminense, 2008.

Hoberman, Michael, et al., eds. Jews in the Americas, 1776-1826. London: Routledge, 2018.

Ioly Zorattini, Pier Cesare. L'identità dissimulata. Firenze: Olschki, 2000.

Ioly Zorattini, Pier Cesare. Processi del Santo Uffizio di Venezia contro Ebrei e Giudaizzanti, 16o8-1632. 14 vols. Florence: Olschki, 1980-1999.

Israel, Jonathan I. "Menasseh Ben Israel and the Dutch Sephardic Colonization Movement." In The Jews of Britain, 1656 to 2000 . Edited by Todd M. Endelman, 15-38. Berkeley: University of California Press, 2002. 
Israel, Jonathan I. Diasporas within a Diaspora: Jews, Crypto-Jews, and the World of Maritime Empires, 1540-1740. Leiden: Brill, 2002.

Israel, Jonathan I. "The Dutch Jewish Enlightenment in Surinam, 1770-180o." In The Religious Cultures of Dutch Jewry. Edited by Yosef Kaplan and Dan Michman, 183206. Leiden and Boston: Brill, 2017.

Kagan, Richard L., and Philip D. Morgan, eds. Atlantic Diasporas: Jews, Conversos, and Crypto-Jews in the Age of Mercantilism, 1500-1800. Baltimore: Johns Hopkins University Press, 2009.

Kaplan, Yosef. Zwischen Neuchristen und neuen Juden. Die verschlungenen Wege von Kryptojuden und westlichen Sefarden in der Frühen Neuzeit. Trier: Kliomedia, 2014.

Kaplan, Yosef. "Wayward New Christians and Stubborn New Jews." Jewish History 8, nos. 1-2 (1994): 27-41.

Kaplan, Yosef, ed. The Dutch Intersection. Leiden: Brill, 2008.

Kaplan, Yosef, and Dan Michman, eds. The Religious Cultures of Dutch Jewry. LeidenBoston: Brill, 2017.

Kiron, Arthur, ed., Constellation of Atlantic Jewish History, 1555-189o. Philadelphia: University of Pennsylvania Press, 2014.

Kistemaker, Renée and Tirtsah Levie, eds. Portugueses em Amesterdão. 1600-1680. Amsterdam: De Bataafsche Leeuw, 1988.

Klooster, Wim. "Atlantic and Caribbean Perspectives: Analyzing a Hybrid and Entangled World." In The Sea: Thalassography and Historiography in the Twenty-First Century. Edited by Peter N. Miller, 6o-83. Ann Arbor: University of Michigan Press, 2013.

Konijn, Fieke. "As sepulturas do cemitério Bet Haim." In Portugueses em Amesterdão. 16oo-168o. Edited by Renée Kistemaker and Tirtsah Levie, 90-109. Amsterdam: De Bataafsche Leeuw, 1988.

Langford Oliver, Vere. Monumental Inscriptions: Tombstones of the Island of Barbados. San Bernardino: Borgo Press, 1995.

Leonard, Adrian, and David Pretel, eds. The Caribbean and the Atlantic World Economy. Circuits of Trade, Money and Knowledge, 1650-1914. Houndmills: Palgrave, 2015.

Levi, Amalia S. "Linked Sephardim: A Prosopography of the Sephardic Community of the Island of Barbados, West Indies." Unpublished manuscript.

Levie Bernfeld, Tirtsah. "Exit Amsterdam: Poor Portuguese and Caribbean Horizons." In A Sefardic Pepper-Pot. Edited by Michael Studemund-Halévy, 210-29. Tirocinio: Barcelona, 2016.

Levie Bernfeld, Tirtsah. Poverty and Welfare Among the Portuguese Jews in Early Modern Amsterdam. Oxford: Littman Library, 2012.

Lieberman. Julia R. "New Practices of Sedaca: Charity in London's Spanish and Portuguese Jewish Community during the Eighteenth Century." In Charity on Jewish, Christian, and Islamic Traditions. Edited by Julia R. Lieberman and Michal Jan Rozbicki, 105-29. Lanham: Lexington Books, 2017. 
Loker, Zvi. Jews in the Caribbean. Evidence on the History of the Jews in the Caribbean Zone in Colonial Times. Jerusalem: Misgav Yerushalayim, 1991.

Malkiel, David. Stones Speak-Hebrew Tombstones from Padua, 1529-1862. Jerusalem: Ben Zvi Institute, 2014.

Marcus, Jacob Rader. The Colonial American Jew, 1492-1776. Vol. 1. Detroit: Wayne State University Press, 1970.

Margolinsky, Julius. 299 Epitaphs on the Jewish Cemetery in St. Thomas, W. I., 1837-1916. Copenhagen: n.p. 1957 .

Merrill, Gordon. "The Role of the Sephardic Jews in the British Caribbean Area during the Seventeenth Century." Caribbean Studies 4 (1964): 32-49.

Miller, Derek Robert. "A Medley of Contradictions. The Jewish Diaspora in St. Eustatius and Barbados." PhD diss., The College of William and Mary, London, 2013.

Mirvis, Stanley. Jewish Treasures of the Caribbean. The Legacy of Judaism in the New World. Atglen: Schiffer Publishing, 2016.

Nahon, Gérard. "Nefusot Yehuda (Bayonne) et Beraha ve-Shalom (Surinam). Livres et lecture au XVIII ème siècle." In A Sefardic Pepper-Pot in the Caribbean. Edited by Michael Studemund-Halévy, 362-428. Barcelona: Tirocinio, 2016.

Oliel-Grausz, Evelyne. "A Study in Intercommunal Relations in the Sephardi Diaspora: London and Amsterdam in the Eighteenth Century." Dutch Jews as Perceived by Themselves and Others. Edited by Yosef Kaplan and Chaya Brasz, 41-58. Leiden: Brill, 2001.

Oliel-Grausz, Evelyne. "Networks and Communication in the Sephardi Diaspora: An Added Dimension to the Concept of Port Jews and Port Jewries." Jewish Culture and History 7 (2004): 61-76.

Oliel-Grausz, Evelyne. "Relations et réseaux intercommunautaires dans la diaspora d'occident au XVII' siècle." PhD diss., Sorbonne, Paris, 2011.

Oppenheim, Samuel. "A List of Jews Made Denizens in the Reigns of Charles II and James II, 1661-1687." Publications of the Jewish Historical Society 20 (1911): 109-13.

Oppenheim, Samuel. "Last Wills of Jews in the British West Indies prior to $1800 . "$ Publications of the Jewish Historical Society 32 (1931): 55-64.

Perelis, Ronnie. Narratives from the Sephardic Atlantic. Blood and Faith. Bloomington: Indiana University Press, 2016.

Philips Cohen, Julia, and Sarah Abrevaya Stein, eds. Sephardi Lives. A Documentary History, 1700-1950. Stanford: Stanford University Press, 2016.

Racine, Karen, and Beatriz G. Mamigonian, eds. The Human Tradition in The Atlantic World, 1500-1850. Lanham: Rowman \& Littlefield Publishers, 2010.

Robles, Jacob. "Names on Stones in Savan Cemetery, Charlotte Amalie, St. Thomas Burials." Unpublished manuscript 1972. 
Rosenbloom, Joseph R. A Biographical Dictionary of Early American Jews. Colonial Times through 180o. Lexington: University Press of Kentucky, 2015.

Samuel, Wilfred S. A Review of the Jewish Colonists in Barbados in the Year 1680 . London: The Jewish Historical Society of England, 1936.

Sanders, Joanne McCrea, ed. Barbados Records. Wills and Administration. 3 vols. Houston: Sanders Historical Publications, 1979-1981.

Schorsch, Jonathan. Black and Jews in the Early Modern World. Cambridge: Cambridge University Press, 2004.

Schorsch, Jonathan. Swimming the Christian Atlantic. Judeoconversos, Afroiberians and Amerindians in the Seventeenth Century. 2 vols. Leiden: Brill, 2009.

Schreuder, Yda. "A True Global Community: Sephardic Jews, the Sugar Trade, and Barbados in the Seventeenth Century." Journal of the Barbados Museum and Historical Society 50 (2004): 166-94.

Schreuder, Yda. "Evidence from the Notarial Protocols in the Amsterdam Municipal Archives about Trade Relationships between Amsterdam and Barbados in the Seventeenth Century." Journal of the Barbados Museum and Historical Society $5^{2}$ (2006): 54-82.

Schreuder, Yda. "The Influence of the Dutch Colonial Trade on Barbados in the Seventeenth Century." Journal of the Barbados Museum and Historical Society 48 (2002): 143-63.

Sealtiel Olsen, Vibeke. "Liste des Sépharades Portugais qui furent payés pour quitter Amsterdam, 1757-1813." Manuscript. Amsterdam, 1999.

Seeman, Erik R. Death in the New World. Cross-Cultural Encounters, 1492-180o. Philadelphia: University of Pennsylvania Press, 2010.

Shilstone, Eustace M. Monumental Inscriptions in the Burial Ground of the Jewish Synagogue at Bridgetown, Barbados. New York: American Jewish Historical Society, 1956.

Snyder, Holly. "A Sense of Place: Jews, Identity and Social Status in Colonial British America, 1654-1831." PhD diss., Brandeis University, 2000.

Snyder, Holly. "Rethinking the Definition of 'Community' for a Migratory Age, 16541830." In Imagining the American Jewish Community. Edited by Jack Wertheimer, 3-27. Brandeis: Brandeis University Press, 2007.

Studemund-Halévy, Michael. "Across the Waters. Sefardic Pioneers from Hamburg in the Caribbean." In A Sefardic Pepper-Pot in the Caribbean. Edited by Michael Studemund-Halévy, 177-83. Barcelona: Tirocinio, 2016.

Studemund-Halévy, Michael. Biographisches Lexikon der Hamburger Sefarden. Hamburg: Christians, 2000. 
Studemund-Halévy, Michael. "Epitaphs in Blood. Crime and Punishment in Sefardic Tombstones," in Jahrbuch Zentrum Jüdische Studien Berlin-Brandenburg 4 (forthcoming).

Studemund-Halévy, Michael. "Les aléas de la foi. Parcours d'un jeune Portugais entre église et synagogue." In Memoria. Festschrift für Michael Brocke. Edited by Birgit Klein, 363-82. Berlin: Metropol, 2005.

Studemund-Halévy, Michael. "More than Images. Sefardi Sepulchral Iconography in the Jewish Cemetery in Bridgetown, Barbados." In A Sefardic Pepper-Pot in the Caribbean. Edited by Michael Studemund-Halévy, 429-88. Barcelona: Tirocinio, 2016.

Studemund-Halévy, Michael. "Portuguese Jewish Cemetery." Nomination for the UNEsco World Heritage List. Nomination Dossier: The Jewish Cemetery HamburgAltona. Edited by Agnes Sommer. Hamburg: Free Hanseatic City of Hamburg. Ministry of Culture, 2017.

Studemund-Halévy, Michael. "Rückkehr mit Widerruf. Ein junger Portugiese zwischen Kirche und Synagoge." In Tribunal der Barbaren? Deutschland und die Inquisition in der Frühen Neuzeit. Edited by Albrecht Burkardt and Gerd Schwerthoff, 255-75. Konstanz and Munich: UVK Verlagsgesellschaft, 2012.

Studemund-Halévy, Michael. "The Persistence of Images: Reproductive Success in the History of Sephardi Sepulchral Art." In The Dutch Intersection. Edited by Yosef Kaplan, 123-47. Leiden: Brill, 2008.

Studemund-Halévy, Michael. "Wanderer der Du hierher kommst, lobe ihre Erinnerung. Der Dialog mit dem Verstorbenen in sefardischen Grabinschriften" (forthcoming).

Sutcliffe, Adam. "Ideas and Space: Heterodoxy, Circulation and Urban Life in the Western Sephardic Diaspora." Unpublished manuscript, 2005.

Sutcliffe, Adam. "Jewish History in an Age of Atlanticism." In Atlantic Diasporas, Jews, Conversos, and Crypto-Jews in the Age of Mercantilism, 1500-180o. Edited by Richard L. Kagan and Philip D. Morgan, 18-30. Baltimore: The Johns Hopkins University Press, 2009.

Teensma, Benjamin N. "De Levensgeschiedenis van Abraham Perengrino, alias Manuel Cardoso de Macedo." Studia Rosenthaliana 10 (1976): 1-36.

Terrell, Michelle M. The Jewish Community of Early Colonial Nevis. Gainesville: University of Florida Press, 2005. Trivellato, Francesca. The Familiarity of Strangers: The Sephardic Diaspora, Livorno, and Cross-Cultural Trade in the Early Modern Period. New Haven: Yale University Press, 2009.

Truxes, Thomas M. “Trading Diasporas.” In The Princeton Companion to Atlantic History. Edited by Joseph C. Miller, 456-62. Princeton, NJ: Princeton University Press, 2015. Verdooner, Dave, and Harmen Snel, eds. Trouwen in Mokum: Jewish Marriage in Amsterdam, 1598-1811. 2 vols. Den Haag: Koninklijke Bibliotheek, n.d. 
Watson, Karl. "New Jewish Tombstones revealed: Additions to Shilstone's Record of Sephardic Tombstones in Bridgetown, Barbados." The Journal of the Barbados Museum \& Historical Society 62 (2016): 152-61.

Watson, Karl. "The Iconography of Gravestones in the Jewish Graveyard, Bridgetown, Barbados." Journal of the Barbados Museum \& Historical Society 50 (2005): 195-212.

Watson, Karl. "Shifting Identities: The Role of Religion, Race and Creolization among the Sephardic Jews of Barbados, 1654 to 1990." In The Jews in the Caribbean. Edited by Jane S. Gerber, 195-222. Oxford: The Littman Library of Jewish Civilization, 2014. Watson, Karl, et al. The Wills of the Jews, 1685-1847. Bridgetown, n.p., n.d.

Wilke, Carsten L. "Dialogue of the Dead. Talking Epitaphs by Sephardi and Ashkenazi Rabbis of Hamburg." Zutot 5, no. 1 (2008): 61-74.

Williams, Caroline A., ed. Bridging the Early Modern Atlantic World. People, Products, and Practices on the Move. Farnham: Ashgate, 2009.

Zacek, Natalie. "A People So Subtle: Sephardic Jewish Pioneers of the English West Indies." In Bridging the Early Modern Atlantic World. People, Products, and Practices on the Move. Edited by Caroline A. Williams, 97-112. Farnham: Ashgate, 2009.

Zacek, Natalie. Settler Society in the English Leeward Islands, 1670-1776. Cambridge: Cambridge University Press, 2010.

Zeldin, Natalie. "Imaging Death: Sepulchral Iconography in the Koenigstrasse Cemetery." Unpublished manuscript.

Zeldin, Natalie. "Skulls, Shields and Narratives." Unpublished manuscript.

Zielonka, D. M. "A Study of the Life of the Jews in Jamaica Reflected in Their Wills, 16921798." MS SC-13489. AJA Cincinnati 1963. 